\section{War pensions (1900-1945): changing models of psychological understanding}

\author{
EDGAR JONES, IAN PALMER and SIMON WESSELY
}

\begin{abstract}
Background War pensions are used to examine different models of psychological understanding. The First World War is said to have been the first conflict for which pensions were widely granted for psychological disorders as distinct from functional, somatic syndromes. In 1939 official attitudes hardened and it is commonly stated that few pensions were awarded for post-combat syndromes.
\end{abstract}

\begin{abstract}
Aims To re-evaluate the recognition of psychiatric disorders by the war pension authorities.
\end{abstract}

\section{Method Official statistics were compared with samples of war pension files from the Boer War and the First and Second World Wars.}

\section{Results Official reports tended to overestimate the number of awards. Although government figures suggested that the proportion of neurological and psychiatric pensions was higher after the Second World War, our analysis suggests that the rates may not have been significantly different.}

\section{Conclusions The acceptance of psychological disorders was a response to cultural shifts, advances in psychiatric knowledge and the exigencies of war. Changing explanations were both a consequence of these forces and themselves agents of change.}

\section{Declaration of interest None.}

E.J. was supported by a grant from the Ministry of Defence.
Once again interest has focused on the question of war-related psychiatric injury, its nature, recognition and the vexed question of legitimate compensation. Conventional wisdom states that such injury was first recognised during the First World War, albeit belatedly. The official History of the Great War claimed that the number of pensions for neurasthenia and shell-shock peaked at 65000 in February 1921 (Johnson \& Rows, 1923). Ahrenfeldt asserted that 'in March 1939, there were about 120000 pensioners who were still in receipt of pensions or had received final awards for primary psychiatric disability (including neurasthenia, shell-shock, effort syndrome, epilepsy and insanity) . . . [which] represented about $15 \%$ of all pensioned disabilities' (Ahrenfeldt, 1958: p. 10). With this experience, the argument goes, the authorities introduced improved selection, training and treatment, thereby avoiding such high figures during the Second World War. In this paper we combine a historical narrative with new data from the War Pensions Agency to question this story.

\section{THE ROYAL HOSPITAL SYSTEM}

In 1685 a system of daily allowances, administered by the Royal Hospital, Chelsea, was introduced for non-commissioned officers and other ranks disabled by wounds or having completed 20 years of service (Dean, 1950: pp. 69-70). Officers incapacitated by combat were also entitled to a pension based on the degree of injury. The Pensions Act of 1806 made an award dependent on the recipient's rank, length of service, character and the climate in which he had soldiered. No schedule of rates existed and military physicians were required to assess the extent to which a serviceman's ability to earn a living in civilian life had been impaired. This system inadvertently opened the door to psychiatric disorders because a soldier suffering from neurasthenia might appear totally incapacitated. If considered genuine and with a good conduct record, he could receive a permanent pension.

The 6276 pension files that survive from the Royal Hospital are not a complete series, being the cases that remained in payment when their administration transferred to the Ministry of pensions in 1916. They probably represent the severest or longest-lived cases. The majority were awarded to Boer War veterans, but 141 $(2.2 \%)$ relate to earlier Victorian campaigns. Of the latter, 19 were granted for unexplained somatic disorders and were justified by the veteran's incapacity and service overseas in what was regarded as a hostile climate. Servicemen who suffered from weakness and fatigue in the absence of an identifiable lesion were diagnosed with debility, whereas those who presented with rapid or irregular heartbeat, precordial pain and shortness of breath without evidence of cardiac disease were classified as cases of palpitation. If a physician believed that an underlying organic pathology existed, then valvular disease of the heart (VDH) was diagnosed, although death certificates have shown that in reality most of these cases were functional.

Disordered action of the heart (DAH) replaced palpitation as a diagnostic term during the 1890s. A War Office inquiry under Earl de Grey in 1865 concluded that 'overwork of ...the use of improper accoutrements and weights' was the cause (Anon., 1865: p. 7). It recommended changes to soldiers' equipment to reduce 'all chance of medical objection on the score of pressure or constriction on the chest, or on muscles, or blood vessels'. A survey by Maclean found that $8.9 \%$ of those admitted to Netley Military Hospital from an overseas posting between 1863 and 1866 were discharged with what were described as 'diseases of the heart; the great majority being men in the prime of life' (Maclean, 1867: p. 161). Maclean considered that poorly designed cross-belts and pack straps were the cause. Myers (1870) showed that of 1635 cardiac admissions only $276(16.9 \%)$ returned to duty. Cases of DAH were acknowledged by the pension authorities when associated with the physical stresses of campaigning in an inhospitable climate. They were not regarded as an effect of psychological stress. 


\section{THE BOER WAR (1899-1902)}

Of the surviving pensions awarded for service in South Africa, 58 were for overt psychological disorders: six for nervous weakness, three for neurasthenia, one for nervous shock, one for hysteria, nine for schizophrenia or delusional state, 16 for manic-depressive psychosis and 22 for melancholia or depression (Jones \& Wessely, 2001). More common, however, were awards for unexplained somatic complaints such as DAH, rheumatism (in the absence of objective signs) and certain forms of debility (Table 1). The highest incidence of DAH was reported in field units of the Royal Army Medical Corps that had been subjected to arduous route marches (Wilson, 1904).

The trend from rural to industrial recruits also was proposed as a cause for DAH: 'the ill-fed, anaemic, under-sized and somewhat neurotic lads, of which the larger cities produce so plentiful a supply as compared with the sturdy, somewhat lethargic country lad' (Anon., 1912: pp. 6-7). The scandal over the underdeveloped physique of volunteers during the Boer War led to the setting up of the Inter-Departmental Committee on Physical Deterioration in 1904. Although it did not repudiate ideas of hereditary degeneration, the report argued that the problem was bound geographically and socially to the poor of the slums (Pick, 1989).

Rheumatism in the absence of objective signs, such as joint swelling or deformity, was another significant cause of discharge during the Boer War. It was considered an effect of hard campaigning, in particular sleeping rough on the veldt in wet conditions. This was both a popularly held belief of servicemen and an explanation adopted by military physicians. For example, Fusilier Dunn (1930), who had a pension for chronic rheumatism, attributed his symptoms to having stood up to his waist in water for 5 hours in trenches at Arundel, Cape Colony.

The increase in the number of awards for functional somatic disorders was, in part, a reflection of changes to the pension system. Because of the large numbers invalided from South Africa and the Royal Hospital's high rejection rate, in 1901 the UK Government set up a Committee on Disability Pensions chaired by Lord Raglan (Stanley, 1901). It concluded that 'the distinction in the treatment of men discharged on account of wounds \&c and those discharged in consequence of disease directly and wholly due to war service should be abolished' (Raglan, 1901: p. 4). As a result, Surgeon-General Muir's committee into wound and injury pensions recommended that 'sunstroke, heat-stroke or lightening stroke may be regarded as "injuries" and that a new category for 'disease on active service' be introduced (Muir, 1902: p. 4).

\section{FIRST WORLD WAR}

Nervous disorders were not on the agenda at the outset of the First World War. Dr Wilson, who had treated combatants in the opening phase of the conflict, reflected popular opinion when he wrote in the BMJ: 'I do not think that the psychologists will get many cases' (Wilson, 1914: p. 807). The authorities were soon disabused as hospitals became flooded with cases of so-called shell-shock. How, then, were these disabled men to be compensated, if at all?

Set up in December 1916, the Ministry of Pensions took over benefit powers from the Admiralty, Chelsea Hospital and the Army Council to make awards 'where the disablement . . . is due to, or aggravated by, military service' (Anon., 1919: p. 152). Criteria for eligibility were revised; awards were no longer to be based on an assessment of a veteran's ability to earn a living wage but were granted according to a standardised schedule. The loss of two or more limbs, for example, entitled a man to a $100 \%$ pension, whereas amputation of a leg above the knee was assessed at $60 \%$ and below the knee at

Table I An analysis of pensions awarded by the Royal Hospital, Chelsea (1854-1913)

\begin{tabular}{lcc}
\hline Disorder & As a single diagnosis & As a multiple diagnosis \\
\hline Disordered action of the heart & $132(2.1 \%)$ & $199(3.2 \%)$ \\
Valvular disease of the heart & $244(3.9 \%)$ & $356(5.7 \%)$ \\
Rheumatism & $158(2.5 \%)$ & $272(4.3 \%)$ \\
Debility & $89(1.4 \%)$ & $392(6.2 \%)$ \\
Schizophrenia and delusional state & $9(0.1 \%)$ & $9(0.1 \%)$ \\
Manic-depressive psychosis & $16(0.3 \%)$ & $18(0.3 \%)$ \\
Depression & $22(0.4 \%)$ & $23(0.4 \%)$ \\
Neurasthenia/nervous weakness & $11(0.2 \%)$ & $20(0.3 \%)$ \\
Gunshot wounds & $2218(35.3 \%)$ & $2268(36.1 \%)$ \\
Other diagnoses & $3021(48.1 \%)$ & $3021(48.1 \%)$ \\
Not recorded & $356(5.7 \%)$ & $356(5.7 \%)$ \\
Total & $6276(100 \%)$ & 6276 \\
\hline
\end{tabular}

Source: PRO, PIN7I/I-6276: War Pension Files from the Royal Hospital, Chelsea.

$50 \%$. Psychological and functional somatic disorders, such as shell-shock, were more difficult to categorise (Merskey, 1991). They are ambiguous in that both symptoms and diagnosis are bound by cultural factors, not least servicemen's convictions about their health and physician's beliefs about acceptable disabilities (Young, 1995).

Mott argued, 'from the point of view of compensation or pension the War Office authorities very properly regard shell-shock as a definite injury' (Mott, 1916: pp. i-ii), although he failed to mention the considerable problems that followed from attempting to implement an apparently straightforward policy decision. The dilemma facing the military doctor was debated in a Lancet editorial for May 1916:

'Some physicians desire . . . to confine the term [shell-shock] to the symptoms appearing after a man has been rendered unconscious by shell explosion, although no actual bodily injury has been sustained, but similar symptoms occur in soldiers who have been simply exposed to shell fire without becoming unconscious. The question arises whether this condition essentially differs from the conditions produced in the ordinary phases of life by shock of various kinds to the nervous system. Traumatic neurasthenia has long been recognised, and shortly after the passing of the Workmen's Compensation Act many men made claims under the Act who were suffering from a variety of symptoms to which the term 'traumatic hysteria' was rightly applied.' (Anon., 1916: p. 1048)

A framework for doctors and officials attempting to manage the flood of shellshock cases was provided by the pre-war debate over the 1911 National Insurance Act. It had been argued that an epidemic of traumatic neuroses had been created because workmen both consciously and 
unconsciously retained symptoms following accidents and injuries.

In April 1918, a sub-committee of the Council of Consultants, chaired by Sir Frederick Treves, a distinguished military surgeon, suggested that shell-shock should be classified either as a severe injury (where recovery was expected) or as a very severe injury if the veteran was not expected to get better (Treves, 1918). In addition, servicemen were examined to ascertain whether their disability was wholly a consequence of service (attributed) or whether an existing disorder had been made worse by service (aggravated). Attributed pensions could be paid for life. Aggravated awards usually were short-lived and were terminated when the effect of war was deemed to have passed.

By March 1918, according to official records, 18596 pensions (5.9\%) had been given for shell-shock, neurasthenia and other nervous complaints. A further $33343(10.5 \%)$ were awarded for cardiac disorders (largely the functional condition DAH), which is the third largest category after wounds to legs and chest complaints (Anon., 1919: p. 140).

\section{SOUTHBOROUGH AND THE CURTAILMENT OF PENSIONS}

As men continued to be discharged from the forces, the number of claims rose and in March 1921 the Ministry reported that a total of 1.3 million war pensions had been granted, creating an annual expenditure of $£ 105.7$ million (Anon., 1922). Facing this demand, the Government had three options, none of which appeared to meet with widespread approval: they could continue to pay awards in the hope that veterans would spontaneously recover, which is not an acceptable policy for a nation facing an economic downturn; they could re- diagnose ex-servicemen and withdraw their pensions, which is a provocative act when veterans' pressure groups were active; or they could attempt to reduce the number of pensioners by offering treatment, although earlier efforts had not proved encouraging. The publication of the Southborough Report in 1922 was designed to settle the debate about the nature of shell-shock, prevent its recurrence in any future war and undermine existing claims for compensation. It recommended that the term should be 'eliminated from official nomenclature' and that such cases should no more be classified 'as a battle casualty than sickness or disease is so regarded' (Southborough, 1922: p. 190). The official view was that well-trained troops, properly led, would not suffer from shell-shock and that the many servicemen who had succumbed to the disorder were either members of Kitchener's hastily assembled Pals' battalions or the unwilling conscripts who followed.

Official accounts suggested that the number of pensions for neurasthenia and shell-shock peaked in 1921 at 65000 (Johnson \& Rows, 1923). By March 1929, the Government claimed that the total had fallen to $55469(7.5 \%)$, although this figure appears to have included organic psychiatric disorders and psychosis (Mitchell \& Smith, 1931: pp. 320-321). An internal Ministry memorandum showed that awards for neurasthenia were lower than published accounts, falling from 32970 in 1927 to 30220 in 1936 (Prideaux, 1939).

Our analysis of surviving First World War pensions suggests that official figures overstated the number of awards for postcombat syndromes (Table 2). The 22756 files held at the Public Record Office are a $2 \%$ sample drawn primarily from London and south-east England. Because of this geographical bias, they represent about two-thirds of the total awarded. An analysis of this sample showed that pensions for neurasthenia, shell-shock, anxiety neurosis and nervous debility together accounted for $4.2 \%$ as a single diagnosis and $5.7 \%$ as a multiple diagnosis, in contrast to the published figure of $7.5 \%$. Few pensions were granted for major mental illnesses.

Sluggish economic performance saw successive administrations attempt to cut public expenditure, and aggravated disorders became an obvious target. Many were terminated on the grounds that the effect of war had passed. Attributed awards were reduced in value, or even ended, if a veteran showed signs of recovery. Dr Culpin questioned whether this policy led to genuine clinical improvement.

'One frequently hears the word 'pensionitis', coupled with the suggestion that to reduce or stop a neurasthenic's pension will aid his recovery

. This was seen in practice in special war hospitals, where good results often followed a gentle intimation that proof of ability to work was a preliminary to discharge. So far then, as a pension removes the need to work it may be harmful. (Culpin, 1921: p. 324)
Yet few pensions for neurasthenia were so generous that they enabled an exserviceman to give up work. Although it may have hindered treatment in some cases, Culpin concluded that the removal of financial compensation would not lead to the remission of symptoms. This theme was apparent in Miller's unconfirmed claims about accident neurosis and the subsequent rebuttals (Miller, 1961; Mendelson, 1982; Tarsh \& Royston, 1985).

\section{THE HORDER CONFERENCE: A HISTORICAL MODEL}

In Autumn 1938, Herwald Ramsbottom, the Minister of Pensions, assembled a committee of service representatives and leading neurologists to make policy recommendations on war syndromes (Shephard, 2000). The Ministry's concern centred on the issue of shell-shock:

'Misguided public opinion raised [shell-shock] . . to the dignity of a new war disease, and it cannot be regarded as a battle casualty, incurable, and justifying discharge from the service, and this view became rapidly widespread amongst the troops.' (Anon., 1939a, Part 30C: p. I)

In July 1939, a conference of service representatives and psychiatrists, under the chairmanship of Lord Horder, helped to frame the Ministry's policy of offering treatment rather than pensions for war syndromes. Published guidance recommended that "such terms as "shell shock", which may suggest that these nervous symptoms have a physical basis or are due directly to injury, must be rigidly avoided' (Anon., 1939b: p. 1201).

\section{THE IMPACT OF WAR}

Once the war had begun, the decision not to award pensions for post-combat syndromes brought the Government into conflict with the Trade Unions over the Workmen's Compensations Acts. The National Union of Seamen raised the case of four crew members of the SS Athenia, which had been torpedoed while carrying valuable supplies to the UK. Although the sailors had not been physically injured, they were traumatised by the experience, and the unions argued that they were eligible for financial compensation (Anon., 1941a). During August 1940, 18.5\% of casualties admitted to first aid posts were diagnosed with psychological 'shock'. In June 1941, it was agreed that they were eligible for 
compensation if the disorder resulted from 'direct exposure to bomb explosion or blast' and left them unable to work (Anon., 1941b). With these precedents, the Ministry found it impossible to exclude soldiers traumatised by the experience of battle if it could be shown that there was no predisposing condition.

One further change to the pensions system had a significant impact on the veterans' position. Public opinion, together with pressure from politicians and doctors, forced the Government to reverse the onus of proof in a disputed application. In 1943, following a ruling made by Lord Denning in the High Court, a claim submitted under Article 4 was deemed to fail only if the Ministry could provide such evidence against it that would secure a guilty verdict in a criminal case. As Sir John Anderson MP, Lord President of the Council, stated:

'We establish the presumption that a man's condition as recorded on his admission to the service was in fact his condition at that time; and that any subsequent deterioration in his condition was due to his service. We provide that there shall be no onus of proof on the claimant and that the benefit of any doubt should be given to the claimant.' (Wooton, 1963: p. 265)

The ruling had an important effect on conditions of unknown or multiple aetiology, which in the past would have been rejected on grounds of insufficient evidence. Many of these claims were now granted because it was difficult to prove that unexplained symptoms had not been caused or aggravated by military service. Sargant believed that this

$\therefore$. . sent the pendulum swinging back too far. Anyone able to prove some sort of wartime stress could draw what was known as an 'aggravated pension', and a great many of these were granted to men who were in part exaggerating their illnesses.' (Sargant, 1967: p. 95).

It has become a given fact that few pensions were granted for psychoneurosis during or immediately after the Second World War (Ahrendfelt, 1958). Shephard stated that 'until 1944 . . . no one was paid a pension for psychoneurotic illness' and despite the change of policy 'the overall attitude remained much tougher than in the previous war and, in a number of quite deserving cases, pensions were denied' (Shephard, 1999: p. 513). Certainly, few pensions for psychoneurosis were awarded in the early years of the war. By September 1941, for example, only $1173(16.7 \%)$ applications had been granted (Anon., 1942). Yet the Ministry's own figures for

Table 2 Analysis of First World War pensions

\begin{tabular}{lrr}
\hline Disorder & As a single diagnosis & Multiple diagnosis \\
\hline Gunshot wounds & $3644(16.0 \%)$ & $4510(19.8 \%)$ \\
Disordered action of the heart & $1149(5.0 \%)$ & $1561 \quad(6.9 \%)$ \\
Valvular disease of the heart & $299(1.3 \%)$ & $369(1.6 \%)$ \\
Rheumatism & $583(2.6 \%)$ & $798(3.5 \%)$ \\
Gassed & $202(0.9 \%)$ & $279(1.2 \%)$ \\
Debility & $568(2.5 \%)$ & $992(4.4 \%)$ \\
Neurasthenia & $817(3.6 \%)$ & $1135(5.0 \%)$ \\
Shell-shock & $73(0.3 \%)$ & $100(0.4 \%)$ \\
Anxiety neurosis & $34(0.2 \%)$ & $41 \quad(0.2 \%)$ \\
Nervous debility & $22(0.1 \%)$ & $26(0.1 \%)$ \\
Depression & $22(0.1 \%)$ & $25(0.1 \%)$ \\
Manic-depressive psychosis & $13(0.1 \%)$ & $18(0.1 \%)$ \\
Schizophrenia & $11(0.1 \%)$ & $12(0.1 \%)$ \\
Psychosis & $25(0.1 \%)$ & $29(0.1 \%)$ \\
Other & $15294(67.2 \%)$ & $15294(67.2 \%)$ \\
Total & $22756(100 \%)$ & 22756
\end{tabular}

Source: Public Record Office, PIN 26/I-22,756.

1953 (Table 3) suggested that $10 \%$ of all pensions awarded to Second World War veterans were for psychological and neurological disorders, which is significantly greater than the $6.3 \%$ for First World War veterans (Anon., 1953). These statistics are supported by invalidity data from the British army. Psychiatric disorders rose in the first half of the 20th century to a peak of $44 \%$ of all medical discharges in 1950 (Bergman \& Miller, 2000).

It is estimated from our survey of the Department of Social Security (DSS) archives that approximately 1098500 applications were made by Second World War veterans. In 1993 the DSS entered all cases that continued in payment and any new retrospective claims into a computer database. These probably represent some of the severest cases because mild or transient disorders would have been terminated in the immediate post-war years on the grounds that military service merely aggravated an existing neurosis. This argument had been given academic force by Slater's investigations into the role of constitutional factors (Slater, 1943). In truth, post-combat syndromes are inevitably the result of an interaction between predisposing, pre-enlistment factors and the experience of military service. As a result, the emphasis put on either variable becomes yet another barometer of attitudes to psychological injury - a hostile climate stressing pre-service constitution and a sympathetic one stressing the traumatic exposure.

The DSS database contained 214820 Second World War cases, which is about one-third of the total granted, and these were analysed by diagnosis. Awards for psychoneuroses represented $1.8 \%$ as a single diagnosis and $2.3 \%$ as a multiple diagnosis (Table 4). Given that these percentages probably understate the actual rate, the true proportion probably lay somewhere between the Ministry's published figure of $10 \%$ and the $2.3 \%$ found in this sample. Extrapolating from these numbers, it is possible that around 30000 pensions were granted for psychoneurosis during the Second World War which is between one-third and a half of those for the First World War. Although this represented an important reduction, the numbers in absolute terms were significant.

\section{DISCUSSION}

\section{Reinterpretation of disorders}

This survey of war pensions has shown that both psychological and functional somatic disorders were subject to evolving models of interpretation. These explanations were both a reflection of cultural shifts (including ideas of hereditary degeneration and the stresses of industrial life) and, as in the case of shell-shock, themselves 
catalysts of change. Wars threw up novel terms for what some regarded as established syndromes. Smith \& Pear argued that 'shell shock involves no new symptoms or disorders. Every one was known beforehand in civil life' (Smith \& Pear, 1917: p. 24). Furthermore, lack of moral fibre, a term restricted to the Royal Air Force, was probably devised in 1940 by the Department of the Air Member for Personnel, with input from Charles Symonds, to provide medical officers with a way of invaliding aircrew without giving them an established psychiatric disorder or directly accusing them of failing courage (Brandon, 1996). It arose at a time when the authorities were seeking strategies to avoid the social and political conflicts that had followed the widespread adoption of the term shell-shock during the First World War.

Because models of psychological understanding changed over the 50 years of this study, pension statistics for post-combat syndromes have to be treated with caution. Although many of the observations made by physicians, such as palpitations or contractures, have a degree of objectivity, others, including exhaustion or depression, contained an element of subjectivity and are more likely to be culturally conditioned. Although pension numbers are not absolute measures, they do, nevertheless, provide an important illustration of new ideas and popular perceptions.

\section{The pension dilemma}

With these caveats in mind, what conclusions can be drawn about war-related psychiatric injury? A pattern does emerge, not so much of a march towards progress, understanding and compassion, but a military two-step of expediency and need. Hence, the wave of sympathy for psychologically damaged servicemen after the First World War led to an official recognition, although this was soon curtailed in response to both economic and moral factors. The post-war depression forced governments to cut public spending, while the military became concerned that compensation for shell-shock could sometimes result in rewarding shirking or even cowardice. Similarly, in the Second World War attempts to limit the impact of psychological-injury claims on the armed forces floundered in the face of pressure from politicians and doctors. Increased emphasis on constitutional, or non-deserving,

Table 3 War pensions in payment at March 1953 compared with First World War totals

\begin{tabular}{|c|c|c|c|c|}
\hline \multirow{2}{*}{$\begin{array}{l}\text { Disorder } \\
\text { Wounds and injuries }\end{array}$} & \multicolumn{2}{|c|}{ First World War veterans } & \multicolumn{2}{|c|}{ Second World War veterans } \\
\hline & 504000 & (37.5\%) & 122572 & $(24.4 \%)$ \\
\hline Rheumatism & 84855 & $(6.3 \%)$ & 7943 & $(1.6 \%)$ \\
\hline Heart disease & 118995 & (8.9\%) & 19814 & $(4.0 \%)$ \\
\hline Epilepsy & 8436 & $(0.6 \%)$ & 1766 & $(0.4 \%)$ \\
\hline $\begin{array}{l}\text { Neurological and mental disorders } \\
\text { (excluding epilepsy) }\end{array}$ & 84681 & $(6.3 \%)$ & 50060 & (10.0\%) \\
\hline Others & $542 I 6 I$ & (40.4\%) & 299281 & (59.7\%) \\
\hline Total & | 343 |28 & $(100 \%)$ & 501436 & \\
\hline
\end{tabular}

Source: Ministry of Pensions, Twenty-Eighth Report . . f for the Period to 3I March 1953, HMSO: London, Appendix 4: p. 97.

Table 4 A sample of Second World War pensions

\begin{tabular}{lrcrl}
\hline Disorder & \multicolumn{2}{c}{ As a single diagnosis } & \multicolumn{2}{c}{ As a multiple diagnosis } \\
\hline Effort syndrome & 19 & $(0.01 \%)$ & 40 & $(0.02 \%)$ \\
Non-ulcer dyspepsia & 105 & $(0.1 \%)$ & 243 & $(0.1 \%)$ \\
Peptic ulcer & 2038 & $(0.9 \%)$ & 3944 & $(1.8 \%)$ \\
Gunshot wounds & 20596 & $(9.6 \%)$ & 21214 & $(9.9 \%)$ \\
Amputation & 1315 & $(0.6 \%)$ & 3179 & $(1.5 \%)$ \\
Psychoneurosis' & 2290 & $(1.1 \%)$ & 4946 & $(2.3 \%)$ \\
Schizophrenia and delusional states & 250 & $(0.1 \%)$ & 413 & $(0.2 \%)$ \\
Manic-depressive psychosis & 10 & $(0.01 \%)$ & 11 & $(0.01 \%)$ \\
Depression & 130 & $(0.1 \%)$ & 352 & $(0.2 \%)$ \\
Others & 188067 & $(87.5 \%)$ & 188067 & $(87.6 \%)$ \\
Total & 214820 & $(100 \%)$ & 214820 &
\end{tabular}

Source: War Pension Agency: historical files.

I. Includes anxiety state, neurosis, adjustment disorder, depression, nervousness, personality disorder and shell-shock.

causes enabled the pension authorities to regain some control over their numbers and management.

Public opinion and the wish to see deserving cases properly remunerated tend to drive governments towards liberal regimes, whereas the need to practise economy, particularly in times of depression, provides a buffer. Tougher regulations are supported by evidence that pensions can inhibit the natural process of recovery and consolidate distressing symptoms. No clear solution presents itself to the war pensions dilemma of how to discourage invalidity and yet compensate the truly deserving. To offer treatment in place of pensions is not the answer because many veterans refuse to participate in a range of therapeutic interventions with uncertain or varied outcomes.

Claims for post-traumatic stress disorder made by former members of the armed forces and public-sector workers, including the police and firemen, are on the increase. This has triggered an active debate within psychiatry, the media and in parliament, focusing on current claims arising from conflicts such as the Falklands, the Gulf and Northern Ireland, tested in the major court case of 2002. In this paper we attempt to bring a historical perspective to bear on this pressing issue.

\section{ACKNOWLEDGEMENTS}

E.J. was supported by a grant from the Ministry of Defence. The Ministry of Defence have had no input into the design, analysis or reporting of this study. Thanks are due to Dr Peter Barham for his helpful comments on an earlier draft of the text.

\section{REFERENCES}

Anon. (1865) Report of the Committee Appointed to Inquire into the Effect on the Health of the Present System of Carrying the Accoutrements, Ammunition, and Kit of Infantry Soldiers. London: HMSO. 
- (1912) Report of the Army Medical Department London: HMSO

- (1916) The diseases of active service. Lancet, i, 1048.

- (1919) First Annual Report of the Minister of Pensions to 31 March 1918. London: HMSO.

- (1922) Work of the pensions ministry. BMJ, i, 68.

- (1939a) Conference on entitlement in neurasthenia and the psychoses (PRO, PINI5/240I).

- (1939b) Neuroses in war time; memorandum for the medical profession. BMJ, ii, 1201 .

- (1941a) Neurasthenia: definition of nervous shock in relation to war injury (PRO, PINI5/2208, 26B6), March 194I.

- (194Ib) Letter to Pontypridd Labour Party (PRO, PINI5/2208, 26B), June 194I.

- (1942) Standing Committee on Neurosis in War approximate numbers dealt with by the Ministry of Pensions from 3 September 1939 to 27 September 1941. (PRO, PINI5/2403, 55B).

- (1953) Ministry of Pensions, Twenty-eighth Report for the Period to 31 March 1953. London: HMSO.

Ahrenfeldt, R. H. (1958) Psychiatry in the British Army in the Second World War. London: Routledge.

Bergman, B. P. \& Miller, S. A. StJ. (2000) Unfit for further service: trends in medical discharge from the British Army 1861-1998. Journal of the Royal Army Medical Corps, 146, 204-21I.

Brandon, S. (1996) LMF in Bomber Command 193945: diagnosis or denouncement? In 150 Years of British Psychiatry, Volume Two (eds H. Freeman \& G. Berrios), pp. 119-129. London: Athlone.

Culpin, M. (1921) The problem of the neurasthenic pensioner. British Journal of Psychology Medical Section, I, 322

Dean C. G. T. (1950) The Royal Hospital Chelsea. London: Hutchinson.

Dunn, T. (1930) War pension file (PRO, PIN7I/279)

Jones, E. \& Wessely, S. (200I) Psychiatric battle casualties: an intra- and interwar comparison. British Journal of Psychiatry, 178, 242-247.

Johnson, W. \& Rows, R. G. (1923) Neurasthenia and the war neuroses. In History of the Great War, Diseases of the War, Volume 2 (eds W. G. Macpherson, W. P. Herringham \& T. R. Elliott), pp. 7, 56. London: HMSO.

Maclean, W. C. (1867) Diseases of the heart in the British Army. The cause and the remedy. BMJ, i, 161-164.

Mendelson, G. (1982) Not cured by a verdict - effect of legal settlement on compensation claimants. Medical Journal of Australia, 2 132-134.

Merskey, H. (199I) Shell-shock. In 150 Years of British Psychiatry 184I-1991 (eds G. E. Berrios \& H. Freeman), pp. 245-267. London: Gaskell.

Miller, H. (1961) Accident neurosis. BMJ, i, 919-925, 992-998.

Mitchell, T. J. \& Smith, G. M. (193I) History of the Great War based on Official Documents, Medical Services. London: $\mathrm{HMSO}$

Mott, F. W. (1916) Special discussion on shell shock without visible signs of injury. Proceedings of the Roya Society of Medicine, $\mathbf{9}, \mathrm{i}-\mathrm{xxiv}$

Muir, S. H. (1902) Report on revised regulations for wounds' and injuries' pensions (PRO,WO33/247).

\section{CLINICAL IMPLICATIONS}

- Although modern wars have generated a variety of post-combat syndromes, their interpretation with regard to disability pensions has proved problematic.

- The award of a war pension for a post-combat syndrome does not resolve the disability, and administrations have found it difficult to reduce their numbers through treatment.

- It appears that a growing awareness of war-related psychiatric injury has led to an increasing proportion of awards for post-combat syndromes.

\section{LIMITATIONS}

- The assessment of psychological disorders requires a degree of subjectivity so that statistics relating to their incidence cannot be compared in an absolute sense across the 50 years of this study.

- Cultural factors affected the diagnostic terms used for post-combat syndromes so that their meaning has changed over time.

- The destruction of many pension files relating to the Boer War and the First World War has forced a reliance on random samples, which may not be totally representative.

EDGAR JONES, PhD, IAN PALMER, MRCPsych, SIMON WESSELY, MD, Department of Psychological Medicine Guy's, King's and St Thomas' Medical School, London

Correspondence: Dr Edgar Jones, Department of Psychological Medicine, GKT School of Medicine, 103 Denmark Hill, London SE5 8RT, UK. E-mail: E.Jones@hogarth7.demon.co.uk

(First received 15 October 200I, final revision 10 January 2002, accepted 14 January 2002)

Myers, A. B. R. (1870) On the Etiology and Prevalence of Diseases of the Heart among Soldiers. London: John Churchill \& Sons.

Pick, D. (1989) Faces of Degeneration, a European Disorder c. 1848-c. 1918. Cambridge: Cambridge University Press.

Prideaux, J. F. E. (1939) Memorandum on entitlement in neurasthenia and psychoses cases (PRO, PINI6/240I).

Raglan, Lord (1901) Report of the Raglan Committee on disability pensions (PRO,WO32/6183), 4(20).

Sargant, w. (1967) The Unquiet Mind. The Autobiography of a Physician in Psychological Medicine. London: Heinemann.

Shephard, B. (1999) 'Pitiless psychology': the role of prevention in British military psychiatry in the Second World War. History of Psychiatry, 10, 49I-524.

- (2000) A War of Nerves, Soldiers and Psychiatrists 1914-1994. London: Jonathan Cape.

Slater, E. (1943) The neurotic constitution. Journal of Neurology and Psychiatry, 6, I-16.

Smith, G. E. \& Pear, T. H. (1917) Shell Shock and its Lessons. Manchester: Manchester University Press.
Southborough, Lord (1922) Report of the War Office Committee of Enquiry into 'Shell-Shock'. London: HMSO

Stanley, Lord (1901) Lord Stanley's memorandum on disability pensions (PRO,WO33/199), Appendix II, 6.

Tarsh, M. J. \& Royston, C. (1985) A follow-up study of accident neurosis. British Journal of Psychiatry, 146, 18-25.

Treves, F. (1918) Memorandum of the Headquarters Medical Board on a report of the Sub-Committee of the Council of Consultants (PRO,WO32/2791).

Wilson, A. (1914) Notes on 150 cases of wounded French, Belgians and Germans. BMJ, ii, 807.

Wilson, W. D. (1904) Report on the Medica Arrangements in the South African War. London: $\mathrm{HMSO}$

Wooton, G. (1963) The Politics of Influence, British Ex-servicemen, Cabinet Decisions and Cultural Change (1917-57). London: Routledge.

Young, A. (1995) The Harmony of Illusions: Inventing Post-traumatic Stress Disorder. Princeton, NJ: Princeton University Press. 